\title{
THE ROLE OF SERVICE QUALITY IMPROVES BRAND IMAGE IN HOTELS XYZ: WORD OF MOUTH AS A MEDIATION
}

\author{
Bonifasius MH Nainggolan ${ }^{1}$, Puan Amidiola ${ }^{2}$ \\ STIE Pariwisata Internasional \\ Email: bonifasius@stein.ac.id,puansar@gmail.com \\ Received: October $10^{\text {th }} 2021$ \\ Approved: November $5^{\text {th }} 2021$
}

\begin{abstract}
This study aims to analyze the effect of service quality on the brand image through word of mouth at Hotel XYZ Jakarta. The population in this study were all guests who came to the Hotel XYZ Jakarta, using primary data obtained from questionnaires with the accidental sampling method. Data samples were obtained from 234 respondents at Hotel XYZ in Jakarta. This study uses non-probability sampling with the SEM method, which is processed by SPSS and SmartPLS programs. The results represent service quality has a direct influence on word of mouth and brand image. Word of mouth also directly influences the brand image and can mediate the relationship between service quality and brand image.
\end{abstract}

Keywords: Service quality; Word of Mouth; Brand Image, Hotel

\section{Introduction}

The development of the times provides many changes and developments in the tourism industry that can be seen from hospitality. Hotel as one of the means of accommodation becomes one of the businesses that are much in demand. From year to year, the number of hotels is increasing, especially in major cities or potential locations such as Jakarta. Every year, there is an increase in the number of hotels. It is starting from local, national to international chain hotels, five-star hotels even to jasmine hotels, with various unique and exciting concepts and styles. So that over time, staying in a hotel is no longer a necessity but a lifestyle.

With so many new hotels popping up, guests have many options to decide where they will stay through several considerations and needs. So the competition is getting 
tighter. For hotels that have been operating for a long time, of course, must have a strategy to be able to survive and compete among the many new hotels. One of the essential things to survive among the many existing hotels is to build and maintain a good brand image. Many guests tend to be more confident and trusting to stay in hotels with a good brand image. (Cho dan Fiore, 2015). So if you already believe in one brand, consumers will tend to survive using/buying the brand.

Brand image is one of the popular variables and has been widely researched by experts. According to Anholt (2007), brand image is almost similar to reputation in brand impressions in the minds of customers or others. Brand image is not static but somewhat influenced by many company decisions over time (Martínez dan Chernatony, 2004). The effect is particular to consumer perceptions about the quality of a company's products and services (Cretu dan Brodie, 2007). Tekin et al. (2016) A strong brand image influences the impression of a brand that can be the key to attracting more consumers deciding to buy a product. If they like the brand after making a purchase, there will usually be a subsequent purchase. This is because consumers tend to be happier and happier when they consume and interact with their favorite brands (Cho dan Fiore, 2015).

The formation of brand image is often influenced by various factors, one of which is the Service quality felt. Where the reason guests stay, one of them is because they want to get good and satisfactory service. Parasuraman et al. (1988) The Service quality compare the quality that consumers expect and the reality they get. All businesses engaged in services, especially hotels, focus on the Service quality to improve satisfaction, loyalty, and brand image. Therefore, the Service quality is significantly related to brand image (Saleem dan Raja, 2014). This is in line with the statement M dan Ali (2017) Service quality has a significant effect on the brand image on different objects. The better the service quality will reflect all the dimensions that provide benefits to customers. However, the relationship of Service quality with a brand image is not always the same. However, in the study at Telkomsel Idris (2014), the Service quality has no significant effect on the brand image.

Thus, between the perception of price and the Service quality to the brand image, an inconsistent relationship causes a gap. To bridge the gap caused, there needs to be communication between customers termed as word of mouth. Word of mouth is 
information in the form of products and or services carried out between customers in informal communication (Dzian et.al, 2015). Ng et al. (2011) argue that word of mouth is significant for service providers (intangible). Moreover, Yaman (2018) While word of mouth can create a positive brand image in their memory, variables proposed to mediate price perception and Service quality to a brand image are word of mouth. Previous studies conducted by Rambe et al. (2017; Somantari dan Rastini (2019) There is an influence between the Service quality on word of mouth. Therefore, Word of Mouth is thought to mediate the gap in the relationship between price perception and service quality to brand image by taking a case study at Hotel XYZ. This research aims: To find out the effect of service quality on word of mouth at Hotel XYZ; To find out the effect of Service quality on the brand image at Hotel XYZ; To find out the influence of word of mouth on brand image in Hotel XYZ; To determine the effect of service quality on brand image through word of mouth at Hotel XYZ.

\section{Literature Review}

\section{Brand Image}

Baines et al. (2004) define imagery in a broad sense as a person's perception based on his knowledge and experience. A company image is a valuable picture of consumers concerning the activities and products of a company. (Kolade et.al, 2014). Meanwhile, Kotler dan Armstrong (2008) A brand is the identity of a product or service from one or a group of sellers that distinguishes it from a competitor by a name, designation, logo, symbol or design, or combination. Bilgin's (2018) Brand statement reflects the value, purity, and commitment related to the goods and services of a company in its business needs with consumers. A brand is a version of a particular brand from a specific class of products (Chaudhuri dan Holbrook, 2001).

Laksana (2008) reveals that the brand has four parts: name, sign, trademark, and copyright. Further afield, Keller (2013) the contributing factors to forming a brand image in a brand association consists of; excellence of brand association, the goodness of brand association, and uniqueness of brand association. 


\section{Service quality}

Quality is conformity with the desired purpose so that anything produced, either goods or services, must be in accordance to make it. (Juran dan De Feo, 2010). According to Jain dan Gupta (2004), quality is a strategy that must be done to achieve operational efficiency and improved performance in a business. Quality is the most important instrument in business strategy that is the basis of competition, the search for consumers that is closely related to the profits generated. (Zehir dan Narcikara, 2016). Zeithaml et al. (2017) Services an act, process, and performance provided, reproduced, or made by one person or group. Service is what a person does with certain requirements to meet the wishes and expectations of others. (Kenyon dan Sen, 2015). Service quality is a customer's evaluation of what they receive, the processes performed, and the environmental situation in which the service is provided. (Zeithaml et.al, 2017). Service quality is the ability of product/service providers to achieve customer satisfaction. (Tripathi, 2017). Slightly different, Sultan (2018) Explains the Service quality is the extent to which intangible products can meet the needs, wants, and expectations of customers towards him. Parasuraman et al. (1988) has identified five dimensions of service quality: physical evidence (tangibles); reliability; responsiveness, assurance, and empathy.

Manhas dan Tukamushaba (2015) In the hospitality industry, the Service quality is an essential factor determining success, which is also an advantage in competing with competitors. The Service quality can affect the customer's word of mouth. Therefore, service providers/products must pay attention to it, so that word of mouth by customers is increasing. (Wahyu dan Gorda, 2017). Dharmawan dan Hidayat (2018) said if the Service quality is higher / perceived both by customers will have a positive and significant effect on word of mouth. Penelitian terdahulu yang dilakukan oleh Agustin e. al (2020); Radiah et.al (2021); Rambe et.al (2017); Somantari dan Rastini (2019) There is an influence between the Service quality on the word of mouth.

In improving the brand image, the product/service provider must pay attention and improve the Service quality because it dramatically affects purchasing behavior by customers. (Rizkalla dan Suzanawaty, 2011). Kurniawan dan Sidharta (2016) pointed out that the Service quality has a significant effect on the brand image, so the higher the Service quality will lead to a higher brand image. Previous research conducted by Abdi 
dan Yuliati (2015); Aisha (2017); dan Wijaya et al. 2020) There is an influence between the Service quality on the brand image. Studies conducted by Yaman (2018) show the impact of word of mouth on brand image. Meanwhile, Foster (2018) revealed that the Service quality has a positive and significant influence on the brand image. In addition, it is also an important indicator for a brand to be able to compete. (Yildiz 2017). Previous research conducted by Narotama (2015) reveals the effect of Service quality on the brand image. Thus, the hypothesis can be formulated as follows:

$\mathrm{H}_{1}$ : Service quality affects word of mouth

$\mathrm{H}_{2}$ : The Service quality affects the brand image.

\section{Word of Mouth}

Word of mouth is an essential part of the scope of professional marketing that prioritizes the principle of trust in influencing consumer choice. (Sweeney et al., 2007). Menurut Jalilvand dan Samiei (2012) Word of mouth is one aspect of disseminating very influential information. Word of mouth is talking about products/services that are advice or inducements for advertising a company's product/service. (Maisam dan Mahsa, 2016).

Meanwhile, Solomon (2019) Word of mouth communication is product information that one person disseminates against another that affects the selection of a product. More with Berger dan Schwartz (2011), Word of mouth is what consumers talk about like the latest thing, a bad experience somewhere, or a pleasant experience somewhere. Based on the results, word of mouth is divided into positive and negative (Sweeney et al., 2007). Further afield, Tuškej et al. (2013) stated in a positive word of mouth that consumers do to people they know, some things are conveyed, among others; tell me about the experience of consuming; recommending the brand; and talk about brands that have good products/ services.

According to Indra (2018), Word of mouth is one of the promotion methods that is very easy and fast to do. Anyone can be the giver and receiver of information. The occurrence of word of mouth is considered to form a perception of a brand because it makes prospective customers have their judgment based on the word of mouth they receive. Therefore word of mouth has a powerful influence on brand image. Pramesti dan Rahanatha (2019) also found a positive and significant influence that word of 
mouth has on brand image, where more word of mouth is done will improve the brand image. Previous research conducted by Rahman et al. (2019); and Randabunga et al. (2021) Found an influence between word of mouth on brand image. Thus, the hypothesis can be formulated as follows: :

$\mathrm{H}_{3}$ : There is a positive influence of word of mouth on brand image.

$\mathrm{H}_{4}$ : The Service quality affects the brand image at Hotel XYZ through word of mouth.

\section{Methodology}

This research method uses structural equation model (SEM) analysis with the population being all guests at Hotel XYZ. The sampling method using nonprobability sampling is Accidental Sampling is a method of determining samples taken based on guests who stayed and obtained 234 data. The distributed questionnaire has been tested for validity and reliability with the number of respondents of 20 people. Tests are conducted with SEM analysis methods using the SmartPLS program. Outer model testing that measures the relationship between observed sizes reflects its latent variable using Confirmatory Factor Analysis(CFA) (Brown, 2015). Convergent validity refers to the extreme loading value of $\geq 0.6$, and construct validity refers to the AVE value of $\geq 0.5$. Reliability refers to composite reliability (C.R.) $\geq 0.7$ and Alpha Cronbach value of $\geq 0.7$ (J. Hair et al., 2017). Discriminant validity refers to the square root value of AVE (Average Variance Extracted). Each construct must be greater than the highest correlation of other constructs. (J. Hair et al., 2017). After testing with the CFA method, the next stage is to create a Structural Equation Model (SEM). The goodness of fit MODEL SEM (Inner Model) refers to the SRMR(Standardized Root Mean Squared Residual) criteria $\leq 0.08$ (Hu \& Bentler, 1999), Efek Ukuran $\left(f^{2}\right)$ and accuracy of predictions $\left(Q^{2}\right)$ (J. Hair et al., 2017). Hypothesis testing refers to the level of significance, $\alpha=5 \%(\quad) t=1.96$. 
Vol.4 No.1, May 2021

\section{Result}

\section{Profile Respondents}

Table 1. Profile Respondents

\begin{tabular}{|c|c|c|c|}
\hline \multirow[t]{2}{*}{ Gender } & Man & 136 & $58,1 \%$ \\
\hline & Woman & 98 & $41,9 \%$ \\
\hline \multirow{4}{*}{ Age } & $<20$ years & 8 & $3,4 \%$ \\
\hline & 20 - 30 years & 148 & $63,3 \%$ \\
\hline & $31-40$ tahun & 59 & $25,2 \%$ \\
\hline & $>41$ years & 19 & $8,1 \%$ \\
\hline \multirow{4}{*}{$\begin{array}{c}\text { Number of } \\
\text { arrivals }\end{array}$} & First & 88 & $37,6 \%$ \\
\hline & 2 times & 98 & $41,9 \%$ \\
\hline & $3-4$ times & 27 & $11,5 \%$ \\
\hline & $>5$ times & 21 & $9 \%$ \\
\hline
\end{tabular}

Based on Table 1 of the 234 respondents who filled out the questionnaire, it can be known that the majority of respondents are men as much as $58.1 \%$, because guests who stay are dominated by male guests thanwomen. While in terms of age, more dominated by guests aged $20-30$ years $(63.3 \%)$, the next age $31-40$ years $(25.2 \%)$ and the smallest age group under 20 years (3.4\%). Of the number of arrivals staying at Hotel XYZ, the frequency of guests staying at most two times (41.9\%), the next first stay (37.6\%) and at least more than five stays $(9 \%)$.

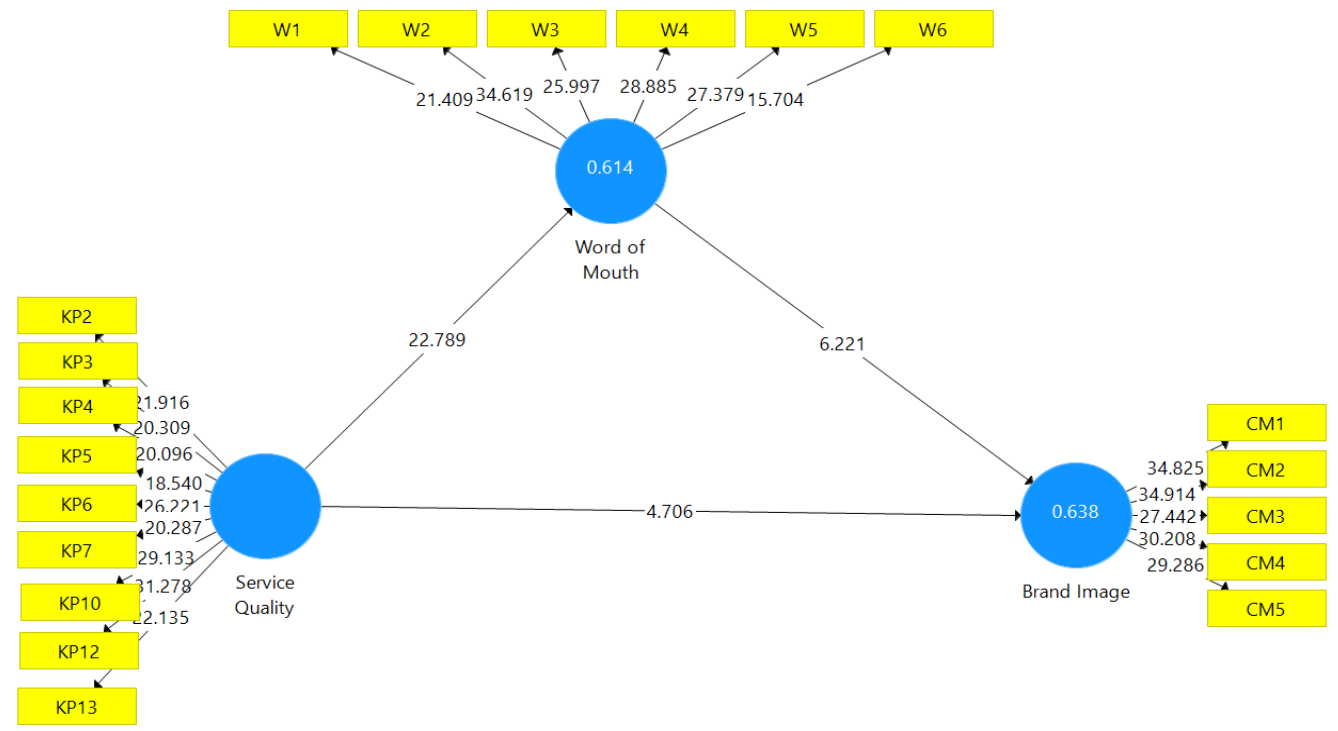

Figure 1. Research Model 


\section{Journal of Management and Leadership}

Vol.4 No.1, May 2021

\section{Convergent Validity}

Validity testing for reflective indicators can be done using the correlation between the indicator's value and its construct value. Measurements with thoughtful hands show a change in an arrow in a construct if other indicators on the exact construct change. Measure by looking at the loading factor value is considered to meet the criteria if the value $>0.7$ (Hair et al., 2014). As in Table 2, the overall indicator has a loading factor above 0.708 and is adequate and meets the convergent value.

Table 2. Convergent Validity Test Results

\begin{tabular}{|c|c|c|c|c|c|c|}
\hline Variable & Indicators & $\begin{array}{l}\text { Loading } \\
\text { Factor }\end{array}$ & $\begin{array}{c}\text { Cronbach } \\
\text { Alpha }\end{array}$ & $\begin{array}{l}\text { Reliability } \\
\text { Composite }\end{array}$ & AVE & Conclusion \\
\hline \multirow{9}{*}{$\begin{array}{l}\text { Service } \\
\text { quality } \\
\text { (X1) }\end{array}$} & KP2 & 0,747 & \multirow{9}{*}{0,903} & \multirow{9}{*}{0,921} & \multirow{9}{*}{0,564} & \multirow{9}{*}{ Good } \\
\hline & KP3 & 0,754 & & & & \\
\hline & KP4 & 0,734 & & & & \\
\hline & KP5 & 0,713 & & & & \\
\hline & KP6 & 0,768 & & & & \\
\hline & KP7 & 0,733 & & & & \\
\hline & KP10 & 0,775 & & & & \\
\hline & KP12 & 0,786 & & & & \\
\hline & KP13 & 0,749 & & & & \\
\hline \multirow{6}{*}{$\begin{array}{c}\text { Word of } \\
\text { Mouth } \\
\text { (Y1) }\end{array}$} & W1 & 0,733 & \multirow{6}{*}{0,868} & \multirow{6}{*}{0,901} & \multirow{6}{*}{0,602} & \multirow{6}{*}{ Good } \\
\hline & W2 & 0,816 & & & & \\
\hline & W3 & 0,783 & & & & \\
\hline & W4 & 0,796 & & & & \\
\hline & W5 & 0,790 & & & & \\
\hline & W6 & 0,735 & & & & \\
\hline \multirow{5}{*}{$\begin{array}{l}\text { Brand } \\
\text { Image } \\
\text { (Y2) }\end{array}$} & CM1 & 0,815 & \multirow{5}{*}{0,866} & \multirow{5}{*}{0,903} & \multirow{5}{*}{0,65} & \multirow{5}{*}{ Good } \\
\hline & CM2 & 0,814 & & & & \\
\hline & CM3 & 0,808 & & & & \\
\hline & CM4 & 0,786 & & & & \\
\hline & CM5 & 0,808 & & & & \\
\hline
\end{tabular}




\section{Journal of Management and Leadership}

Vol.4 No.1, May 2021

\section{Discriminant Validity}

In the discriminant validity test, one way to measure it is to look at the value of cross loading factor; an indicator is declared valid if it has the highest loading factor value to the intended construct compared to the loading factor value to other constructs (Hair et al., 2014). From table 3, numbers printed boldly show the maximum number in each row. It appears that the loading factor of each indicator against the variable or construct of the destination has the most significant value, and this indicates that latent constructs predict indicators on their blocks better than indicators in other blocks.

Table 3. Discriminant Validity Test Results

\begin{tabular}{|c|c|c|c|c|}
\hline Indicators & Service quality (KP) & $\begin{array}{c}\text { Word of Mouth } \\
\text { (W) }\end{array}$ & $\begin{array}{c}\text { Brand Image } \\
\text { (CM) }\end{array}$ & Conclusion \\
\hline KP2 & 0,747 & 0,653 & 0,605 & Good \\
\hline KP3 & 0,754 & 0,571 & 0,495 & Good \\
\hline KP4 & 0,734 & 0,561 & 0,491 & Good \\
\hline KP5 & 0,713 & 0,524 & 0,498 & Good \\
\hline KP6 & 0,768 & 0,606 & 0,613 & Good \\
\hline KP7 & 0,733 & 0,545 & 0,559 & Good \\
\hline KP10 & 0,775 & 0,594 & 0,582 & Good \\
\hline KP12 & 0,786 & 0,667 & 0,582 & Good \\
\hline KP13 & 0,749 & 0,554 & 0,562 & Good \\
\hline W1 & 0,603 & 0,733 & 0,528 & Good \\
\hline W2 & 0,641 & 0,816 & 0,670 & Good \\
\hline W3 & 0,662 & 0,783 & 0,621 & Good \\
\hline W4 & 0,626 & 0,796 & 0,607 & Good \\
\hline W5 & 0,600 & 0,790 & 0,615 & Good \\
\hline W6 & 0,499 & 0,735 & 0,507 & Good \\
\hline CM1 & 0,642 & 0,660 & 0,815 & Good \\
\hline CM2 & 0,554 & 0,620 & 0,814 & Good \\
\hline CM3 & 0,521 & 0,567 & 0,808 & Good \\
\hline CM4 & 0,584 & 0,592 & 0,786 & Good \\
\hline CM5 & 0,668 & 0,640 & 0,808 & Good \\
\hline
\end{tabular}




\section{Construct Reliability}

The construct reliability test is measured through two criteria: Cronbach's Alpha and Composite Reliability from the indicator block that measures the construct. Construct is declared reliable if Cronbach's alpha and composite reliability values are above 0.70 (Hair et al., 2014). As seen in Table 2, the entire construct in the model has a value of Cronbach's Alpha and Composite Reliability $>0.70$. So that all statements on the indicator are reliable and adequate.

Evaluation of Structural Model (Inner Model)

Construct Multicollinearity Test

Table 4 shows all Variance Inflation Factor (VIF) inner values smaller than five so that it is concluded that all constructs are related to each other, and there is no multicollinearity disorder (Hair et al., 2014)

Table 4. Vif Inner Value

\begin{tabular}{lcc}
\hline Variable & $\begin{array}{c}\text { Word of } \\
\text { Mouth }\end{array}$ & $\begin{array}{c}\text { Brand } \\
\text { Image }\end{array}$ \\
\hline $\begin{array}{l}\text { Service } \\
\text { quality }\end{array}$ & 1,000 & 2,592 \\
\hline $\begin{array}{l}\text { Word of } \\
\text { Mouth }\end{array}$ & & 2,592 \\
\hline
\end{tabular}

\section{Coefficient of Determination (R-Square)}

Hair et al. (2014) states the value of R-squares for each endogenous variable as the predictive strength of a structural model used to explain the effect of a particular exogenous variable on an endogenous variable whether it has a substantive impact. The values of R-squares $0.75,0.50$, and 0.25 can be concluded that the model is robust, moderate, and weak. The results of Table 5 show that $61.4 \%$ of word-of-mouth variables are affected by service quality variables. While the brand image variable as much as $63.8 \%$ is influenced by the Service quality and word of mouth. 
Vol.4 No.1, May 2021

Table 5. Value $\mathrm{R}^{2}$

\begin{tabular}{lcc}
\hline Variable & $\mathrm{R}^{2}$ & Conclusion \\
\hline $\begin{array}{l}\text { Word of } \\
\text { Mouth }\end{array}$ & 0,614 & Moderate \\
\hline $\begin{array}{l}\text { Brand } \\
\text { Image }\end{array}$ & 0,638 & Moderate \\
\hline
\end{tabular}

\section{Size Effect (F-Square)}

Calculate the size effect on the model to see if the removed construct has a substantive impact on endogenous construct construction (Hair et al., 2014). Based on Table 6, the size effect of the Service quality variable against Word of Mouth is $>0.35$, so that the value is significant. However, the impact of the Service quality measure on Brand Image is $<0.15$, so the weight is small. At the same time, the effect of word of mouth size on brand image is $>0.15$, so its value is moderate.

Table 6. Value $\mathrm{f}^{2}$

\begin{tabular}{lcc}
\hline Variabel & $\mathrm{f}^{2}$ & Conclusion \\
\hline Service quality $\rightarrow$ Word of & 1,592 & Good \\
Mouth & & \\
\hline Word of Mouth $\rightarrow$ Brand Image & 0,247 & Moderate \\
\hline Service quality $\rightarrow$ Brand Image & 0,141 & Bad \\
\hline
\end{tabular}

\section{Accuracy of Prediction (Q-Square)}

Hair et al. (2014) explain that accuracy prediction or $\mathrm{Q}^{2}$ is an observation of how well the path model can predict the variables studied. If the size effect value is at 0.02 , then it is worth a small amount. If the value is 0.15 , then the category is moderate, and if it is worth 0.35 means significant. Based on Table 7, the accuracy value of word of mouth variable prediction and brand image $>0.35$. Both have high predictive accuracy. 
Table 7. Value $\mathrm{Q}^{2}$

\begin{tabular}{lcc}
\hline Variables & $\mathrm{Q}^{2}$ & Conclusion \\
\hline Word of Mouth & 0,361 & Good \\
\hline Brand Image & 0,406 & Good \\
\hline
\end{tabular}

\section{SRMR (Standardized Root Mean Square Residual)}

Hair et al. (2014) states that SRMR is the square root of the fair difference of the implied matrix with the empirical correlation matrix. It is an absolute model match value. The smaller the difference from the estimated model with the results, the better the model. The SRMR value is said to be good if $<0.08$. The model is said to be getting better if the value of the SRMR gets smaller, even rated perfect if the value is 0 (Hu and Bentler, 1999). Henseler et al. (2014) state that SRMR has the advantage because it is considered the most appropriate in assessing the suitability of composite factor models with data. In Table 8, the value of SRMR is 0.059 , so the model is considered appropriate.

Tabel 8. SRMR Test

$$
\begin{aligned}
& \text { Original } \\
& \text { Sample Conclusion }
\end{aligned}
$$

\begin{tabular}{lcc}
\hline $\begin{array}{l}\text { Model } \\
\text { Saturated }\end{array}$ & 0,059 & Good \\
\hline $\begin{array}{l}\text { Estimation } \\
\text { Model }\end{array}$ & 0.059 & Good \\
\hline
\end{tabular}

\section{Hypothesis Testing}

Hypothesis testing is to find out if there are between variable influences in the model. The relationship between variables is significant if T-statistics are worth more than T-tables and P-values are less than 0.05 (Hair et al., 2017). In this study, the Ttable used was 1.96. Table 10 contains path coefficient information along with Tstatistical values and P-values obtained from smartPLS bootstrapping calculations. The information in this table becomes a reference in evaluating hypotheses. 
Tabel 10. Path Coefficient Value

\begin{tabular}{|c|c|c|c|c|c|}
\hline $\begin{array}{c}\text { Influence Between } \\
\text { Variables }\end{array}$ & $\begin{array}{l}\text { Original } \\
\text { Sample } \\
\text { (O) }\end{array}$ & $\begin{array}{l}\text { Standard } \\
\text { Deviation } \\
\text { (STDEV) }\end{array}$ & $\begin{array}{c}\text { T Statistics } \\
(|\mathrm{O} / \mathrm{STDEV}|)\end{array}$ & $\begin{array}{c}\text { p- } \\
\text { values }\end{array}$ & Conclusion \\
\hline \multicolumn{6}{|l|}{ Direct Influence } \\
\hline $\begin{array}{l}\text { Service quality } \rightarrow \text { Word of } \\
\text { Mouth }\end{array}$ & 0,784 & 0,034 & 22,789 & 0,000 & Significant \\
\hline $\begin{array}{l}\text { Service quality } \rightarrow \text { Brand } \\
\text { Image }\end{array}$ & 0,364 & 0,077 & 4,706 & 0,000 & Significant \\
\hline $\begin{array}{l}\text { Word of Mouth } \rightarrow \text { Brand } \\
\text { Image }\end{array}$ & 0,481 & 0,077 & 6,221 & 0,000 & Significant \\
\hline \multicolumn{6}{|c|}{ Pengaruh Tidak Langsung } \\
\hline $\begin{array}{c}\text { Word of Mouth } \rightarrow \text { Service } \\
\text { quality } \rightarrow \text { Brand Image }\end{array}$ & 0,377 & 0,068 & 5,571 & 0,000 & Significant \\
\hline
\end{tabular}

\section{Direct Effect}

Effect of service quality on word of mouth

The results of the first hypothesis test showed that the relationship between service quality and word of mouth had a path coefficient value of 0.784 (positive) with a statistical $\mathrm{T}$ is 22.78924 , which was more significant than T-table 1.96. Meanwhile, the value of the P-value is 0.000 , which is smaller than 0.05 . Thus it was concluded that the Service quality had a positive and significant effect on word of mouth at Hotel XYZ. The first hypothesis is accepted. Therefore, it can be said that the Service quality at Hotel XYZ has been considered suitable to encourage word of mouth communication. The results of this study follow previous research conducted by, found an influence between the Service quality to word of mouth on different objects.

Manhas and Tukamushaba (2015) say that in the hospitality industry, Service quality is an essential factor that determines success which is also an advantage in competing with competitors. It indicates that all aspects of the service quality at Hotel $\mathrm{XYZ}$ have been fulfilled and have an advantage in the eyes of guests, which will 
encourage the occurrence of word of mouth. Dharmawan and Hidayat (2018) expressed that if the Service quality is higher / perceived both by customers will have a positive and significant effect on word of mouth. Thus, Hotel XYZ must pay attention to the service aspect because the better the Service quality will increase the desire of guests to do word of mouth.

Effect of service quality on brand image

The results of the second hypothesis test showed that the relationship between price perception and brand image had a path coefficient value of 0.364 (positive), with a statistical $\mathrm{T}$ is 4.706 greater than $\mathrm{T}$-table 1.96. Meanwhile, the P-value of 0.000 is smaller than 0.05 . That means the Service quality has a positive and significant effect on the brand image. Therefore, the fourth hypothesis is accepted. These results are the following research conducted by, which found that the Service quality has a positive and significant effect on brand image on different objects.

Manhas and Tukamushaba (2015) stated that service quality becomes a benchmark of performance and customer satisfaction targets to improve brand image. Besides the better the Service quality felt, will improve the cheerful appearance of the hotel. Their experience will affect the impact on the brand. To enhance brand image, product/service providers must pay attention and improve Service quality because it dramatically affects purchasing behavior by customers (Rizkalla and Suzanawaty, 2011). Therefore, Hotel $\mathrm{XYZ}$ is expected to provide the best service experience to guests staying to improve their brand image in guests' minds.

Influence of word of mouth variables on brand image

The third hypothesis test result showed that the relationship between word of mouth and brand image had a path coefficient value of 0.481 (positive) with a statistical $\mathrm{T}$ is 6.221 greater than T-table 1.96. Meanwhile, the P-value of 0.000 is smaller than 0.05. So that means that word of mouth has a positive and significant effect on the brand image. Thus, the third hypothesis is accepted. These results are similar to previous studies conducted, which found that word of mouth significantly affects brand image on different objects. 
According to Indra (2018), word of mouth is considered to form perceptions of a brand because it makes prospective customers have their assessment based on the word of mouth they receive. So what one tells you about the Hotel XYZ will shape the perception of the brand image. Pramesti and Rahanatha (2019) also found a positive and significant influence that word of mouth has on brand image, where more word of mouth is done will improve brand image. The better reviews and experiences they hear from people around them (coworkers, family, and others), then they'll think the hotel is good. Instead, the worse the experience and reviews received, they will conclude the hotel was not good. Therefore word of mouth has a powerful influence on brand image.

\section{Indirect Effect}

Effect of service quality on the brand image through word of mouth.

The indirect influence value between the service quality variable and the brand image through word of mouth was 0.377 (positive). A statistical T-statistic is 5.71, more significant than the T-table of 1.96. Meanwhile, the value of the P-value of 0.000 is smaller than 0.05. Thus it is concluded that the Service quality has an indirect and significant effect on the brand image through word of mouth at Hotel XYZ. The fourth hypothesis is accepted. Research combining service quality, word of mouth, and brand image are relatively limited. However, a previous study conducted by Prikurnia (2021) found an influence between Service quality on word of mouth. Narotama (2015) found the impact of Service quality on brand image. A study conducted by Yaman (2018) showed the influence of word of mouth on brand image.

The study results found that Service quality influences the brand image in Hotel XYZ through word of mouth. The better the Service quality that is felt will increase the desire to tell or recommend it to others. A recommendation is a form of word of mouth that guests do because of good service quality, affecting the brand image. Positive suggestions and stories about the Hotel XYZ will form a positive brand image of the person it tells. So, indirectly the Service quality can improve the brand image by mediating by word of mouth. So Hotel XYZ must pay attention to service quality because it can affect the brand image through word of mouth done by guests. 


\section{Conclusion and Recommendation}

\section{Conclusion}

After completing the research on Hotel XYZ, the authors found the following conclusions:

1. The Service quality significantly affects word of mouth at Hotel XYZ with a contribution of 0.788 .

2. The Service quality significantly affects the brand image at Hotel XYZ with a contribution of 0.364 .

3. Word of Mouth had a significant effect on the brand image at Hotel XYZ with a contribution of 0.481 .

4. The Service quality indirectly affects the brand image of word of mouth at Hotel $\mathrm{XYZ}$ with a contribution of 0.377 .

\section{Recommendation}

Based on the conclusion of the study results, the following are concluded suggestions as consideration for Hotel XYZ for input in future decision making. Requests that the author can give include:

1. Hotel XYZ is expected to provide training to staff to improve the service they do to guests so that it is better and makes guests trust and be noticed during their stay.

2. For further researchers, it is recommended to develop research using other variables such as service experience, alternative appeal, customer value, and satisfaction that may positively affect the occurrence of a word of mouth and brand image.

\section{References:}

A, P., Valerie A, Z., \& Leonard I, B. (1988). SERVQUAL- A Multiple-Item Scale for Measuring Consumer Perceptions of Service quality.pdf. In Journal of Retailing (Vol. 64, pp. 21-40).

Abdi, R. M., \& Yuliati, A. L. (2015). Pengaruh Kualitas Pelayanan terhadap Kepuasan Konsumen dan Citra Merek (Brand Image) pada Shuttle Bus Primajasa

Batununggal Indah Bandung Tahun 2015. 2(X), 3928-3935. 
Agustin, R., Hendriani, S., \& Syapsan. (2020). The Effect of Brand Image and Service quality on Purchase Decision With Word of Mouth as Mediation Variable at Prof. Dr. Tabrani Hospital Pekanbaru. International Journal of Economic, Business and Applications, November, 25-44.

Aisha, N. (2017). Analisis Pengaruh Kualitas Produk dan Kualitas Pelayanan terhadap Citra Merek PT Bank SUMUT pada Nasabah PT Bank SUMUT Cabang Medan Iskandar Muda. Jurnal Samudra Ekonomi Dan Bisnis, 8(2), 736-748. https://doi.org/10.33059/jseb.v8i2.431

Anholt, S. (2007). COMPETITIVE IDENTITY; The New Brand Management for Nations, Citties and Regions. Palgrave Macmillan UK.

Baines, P., Egan, J., \& Jefkins, F. (2004). Public Relations : Contemporary Issued and Techniques. In Angewandte Chemie International Edition, 6(11), 951-952. Elsevier Ltd.

Bass, B. M., \& Riggio, R. E. (2006). Transformational Leadership. In Lawrence Erlbaum Associates, Inc., Publishers 10 Industrial Avenue Mahwah, New Jersey 07430 www.erlbaum.com (Second Edi). Lawrence Erlbaum Associates, Inc., Publishers 10 Industrial Avenue Mahwah, New Jersey 07430 www.erlbaum.com. https://doi.org/10.1093/itnow/bwaa120

Berger, J., \& Schwartz, E. M. (2011). What Drives Immediate and Ongoing Word of Mouth? Journal of Marketing Research, 48(5), 869-880. https://doi.org/10.1509/jmkr.48.5.869

Bilgin, Y. (2018). The Effect Of Social Media Marketing Activities On Brand Awareness, Brand Image, and Brand Loyalty. Business and Management Studies : An International Journal, 6(1), 128-148.

Brown, T. A. (2015). Confirmatory Factor Analysis for Applied Research. In T. D. Little (Ed.), The Guilford Press A Division of Guilford Publications, Inc. 72 Spring Street, New York, NY 10012 www.guilford.com (Second Edi). https://doi.org/10.1198/tas.2008.s98

Chaudhuri, A., \& Holbrook, M. B. (2001). The chain of effects from brand trust and brand affect to brand performance: The role of brand loyalty. Journal of Marketing, 65(2), 81-93. https://doi.org/10.1509/jmkg.65.2.81.18255 
Cho, E., \& Fiore, A. M. (2015). Conceptualization of a Holistic Brand Image Measure For Fashion-Related Brands. Journal of Consumer Marketing, 32(4), 33.

Cretu, A. E., \& Brodie, R. J. (2007). The influence of brand image and company reputation where manufacturers market to small firms : A customer value perspective. 36, 230-240. https://doi.org/10.1016/j.indmarman.2005.08.013

Dharmawan, E., \& Hidayat, I. (2018). Pengaruh Kualitas Layanan Dan Brand Image Terhadap Word of Mouth ( Wom ) Yang Dimediasi Kepuasan Konsuen. Jurnal Ilmu Manajemen Dan Riset Manajemen, 7, 1-19.

Dzian, M., Triznova, M., Kaputa, V., \& Supin, M. (2015). The Analysis of WOM in Slovak Republic and Impact of WOM on Consumers' Purchasing Decision. Procedia Economics and Finance, 26(15), 975-981. https://doi.org/10.1016/s22125671(15)00919-3

Foster, B. (2018). The Influence of Service quality on Aircraft's Brand Image in Bandung, Indonesia. Journal of International Business Research and Marketing, 3(5), 19-24. https://doi.org/10.18775/jibrm.1849-8558.2015.35.3003

George, E., \& K.A., Z. (2018). Psychological Empowerment and Job Satisfaction in the Banking Sector. In Palgrave Macmillan Gewerbestrasse 11, 6330 Cham, Switzerland. Palgrave Macmillan.

Hair, J. F. J., Hult, G. T. M., Ringle, C. M., \& Sarstedt, M. (2014). Partial Least Squares Structural Equation Modeling (PLS-SEM). In Practical Assessment, Research and Evaluation. SAGE Publications.

Hair, J., Hult, G. T., Ringle, C., \& Sarstedt, M. (2017). A Primer on Partial Least Squares Structural Equation Modeling (PLS-SEM) - Joseph F. Hair, Jr., G. Tomas M. Hult, Christian Ringle, Marko Sarstedt. In Sage Publications, Inc.

Haleem, F., Jehangir, M., \& Khalil-Ur-Rahman, M. (2018). Job satisfaction from leadership perspective. Proceedings of the International Conference on Business Excellence, 12(1), 363-373. https://doi.org/10.2478/picbe-2018-0032

Hayes, D. K., \& Ninemeier, J. D. (2009). Human Resource Management in the Hospitality Industry. In John Wiley \& Sons, Inc. Hoboken, New Jersey. John Wiley \& Sons, Inc. Hoboken, New Jersey.

Henseler, J., Dijkstra, T. K., Sarstedt, M., Ringle, C. M., Diamantopoulos, A., Straub, D. W., Ketchen, D. J., Hair, J. F., Hult, G. T. M., \& Calantone, R. J. (2014). 
Common Beliefs and Reality About PLS: Comments on Rönkkö and Evermann (2013). Organizational Research Methods, 17(2), 182-209.

https://doi.org/10.1177/1094428114526928

Hu, L. T., \& Bentler, P. M. (1999). Cutoff criteria for fit indexes in covariance structure analysis: Conventional criteria versus new alternatives. Structural Equation Modeling, 6(1), 1-55. https://doi.org/10.1080/10705519909540118

Idris, T. R. F. (1985). Pengaruh Corporate Social Responsibility (CSR), Kualitas Pelayanan dan Promosi Terhadap Brand Image Telkomsel di Kota Padang. Ecquid Novi: African Journalism Studies, 6(1), 13-21. https://doi.org/10.1080/02560054.1985.9652947

Indra, C. (2018). Pengaruh Word of Mouth Terhadap Purchase Intentiondengan Brand Image Dan Perceived Service quality Sebagai Variabel Intervening Pada Program Kpr Bersubsidi Di Surabaya. Jurnal Manajemen Pemasaran, 12(1), 1. https://doi.org/10.9744/pemasaran.12.1.1-9

Jain, S. K., \& Gupta, G. (2004). Measuring Service quality: Servqual vs. Servperf Scales. Vikalpa, 29(2), 25-38. https://doi.org/10.1177/0256090920040203

Jalilvand, M. R., \& Samiei, N. (2012). The effect of electronic word of mouth on brand image and purchase intention: An empirical study in the automobile industry in Iran. Marketing Intelligence and Planning, 30(4), 460-476. https://doi.org/10.1108/02634501211231946

Juran, J. M., \& De Feo, J. A. (2010). Juran' S Quality Handbook. In Training for Quality (6th ed.). McGraw-Hill Companies.

Keller, K. L. (2013). Strategic Brand Management'. In Journal of Brand Management (Global). Pearson Education. https://doi.org/10.1057/bm.1998.36

Kenyon, G. N., \& Sen, K. C. (2015). The Perception of Quality: Visual Color. In Perceptual Coherence. Springer. https://doi.org/10.1093/acprof:oso/9780195169645.003.0007

Kolade, O. J., Oluseye, O. O., \& A, O. O. (2014). Organizational Citizenship Behaviour, Hospital Corporate Image and Performance. Journal of Competitiveness, 6(1), 36-49. https://doi.org/10.7441/joc.2014.01.03

Kotler, P., \& Armstrong, G. (2008). Prinsip-prinsip Pemasaran (12 (ed.)). Erlangga. Kurniawan, P., \& Sidharta, I. (2016). SERVQUAL on brand image and relationship 
equity. International Review of Management and Marketing, 6(4), 866-871.

M, A., \& Ali, H. (2017). Model Kepuasan Pelanggan: Analisis Kualitas Produk Dan Kualitas Layanan Terhadap Citra Merek Pada Giant Citra Raya Jakarta. Jurnal Manajemen, 21(3), 317. https://doi.org/10.24912/jm.v21i3.254

Maisam, S., \& Mahsa, R. (2016). Positive Word of Mouth Marketing: Explaining the Roles of Value Congruity and Brand Love. Journal of Competitiveness, 8(1), 1937. https://doi.org/10.7441/joc.2016.01.02

Manhas, P. S., \& Tukamushaba, E. K. (2015). Understanding service experience and its impact on brand image in hospitality sector. International Journal of Hospitality Management, 45, 77-87. https://doi.org/10.1016/j.ijhm.2014.11.010

Martínez, E., \& De Chernatony, L. (2004). The effect of brand extension strategies upon brand image. Journal of Consumer Marketing, 21(1), 39-50. https://doi.org/10.1108/07363760410513950

Narotama, A. (2015). The Effect of Service quality on Customer Loyalty with Brand Images and Customer Satisfaction as Mediation. Jurnal Manajemen Dan Kewirausahaan, 7(1), 86-93.

Ng, S., David, M. E., \& Dagger, T. S. (2011). Generating positive word-of-mouth in the service experience. Managing Service quality, 21(2), 133-151. https://doi.org/10.1108/09604521111113438

Pramesti, I. A. C., \& Rahanatha, G. B. (2019). PERAN BRAND IMAGE MEMEDIASI PENGARUH WORD OF MOUTH ( WOM ) TERHADAP NIAT BELI

KONSUMEN Fakultas Ekonomi dan Bisnis Universitas Udayana ( Unud ), Bali , Indonesia Niat beli adalah tahap kecenderungan responden untuk bertindak sebelum benar-benar melakukan. E-Journal Riset Manajemen, 8(1), 7073-7101.

Prikurnia, A. K. (2021). PENGARUH KUALITAS PELAYANAN, HARGA, DAN NILAI PELANGGAN TERHADAP KEPUASAN KONSUMEN YANG DIMEDIASI OLEH VARIABEL WORD OF MOUTH (Studi Kasus Pada Usaha Barbershop di Kabupaten Tulang Bawang Barat). Journal of Economic and Bussiness Retail, 1(1), 44-53.

Radiah, E., Utami, S., \& Chan, S. (2021). The effect of service quality and company image on word of mouth with satisfaction and trust as mediating variables on lion air airlines in Indonesia. International Journal of Multidisciplinary Research and 
Growth Evaluation, 2(4), 634-643.

Rahman, F. Y., Yuliati, L. N., \& Simanjuntak, M. (2019). The Influence of Marketing Mix and Word of Mouth Towards Brand Image and Usage of Online Bike Usage. Indonesian Journal of Business and Entrepreneurship, 5(3), 287-298.

https://doi.org/10.17358/ijbe.5.3.287

Rambe, N., Maksum, C., \& Jasin, M. (2017). Pengaruh Pelayanan, Citra Merek, dan Harga Terhadap Pembelian Ulang Melalui Kepuasan Pelanggan dan Word of Mouth. EKOBISMAN, 1(3), 241-261.

Randabunga, P. E., Hudayah, S., \& Indriastuti, H. (2021). The Effect of Electronic Word and Sales Promotion on Brand Switching with Brand Image as an Intervening Variable et Erha Beauty Clinic in Samarinda City. Saudi Journal of Bussines and Management Studies, 6(4), 102-113.

Reed, S. M. (2017). Compensation and Benefits. In A Guide to the Human Resource Body of Knowledge (pp. 245-286).

Rizkalla, N., \& Suzanawaty, L. (2011). The Effect of Store image and Service quality on Brand Image and Purchase Intention For Private Label Brands. Asean Marketing Journal, 4(2), 90-99. https://doi.org/10.1016/j.ausmj.2010.11.001

Robbins, S. P., \& Judge, T. A. (2013). Organizational Behavior. In Pearson Education, Inc., publishing as Prentice Hall (15th Editi). Pearson Education, Inc., publishing as Prentice Hall.

Saleem, H., \& Raja, N. S. (2014). The impact of service quality on customer satisfaction, customer loyalty and brand image: Evidence from hotel industry of Pakistan. Middle - East Journal of Scientific Research, 19(5), 706-711. https://doi.org/10.5829/idosi.mejsr.2014.19.5.21018

Sidharta, M. W., Syah, T. Y. R., \& Saptaningsih, A. B. (2021). The Relationship Between Social Media Communication and Word of Mouth Inside Brand Image and Purchase Intention. Journal of Multidisciplinary Academic, 05(01).

Solomon, M. R. (2019). Consumer Behavior. In Angewandte Chemie International Edition, 6(11), 951-952. (13th ed.). Pearson Education.

Somantari, M. A., \& Rastini, N. M. (2019). PERSEPSI HARGA TERHADAP WOM PADA LAYANAN GO-JEK DI DENPASAR. E-Jurnal Manajemen, 8(4), 24662494. 
Sultan, A. A. P. (2018). Demographic Differences In Jordanian Bank Service quality Perceptions. The Eletronic Library, 34(1), 1-5.

Sweeney, J. C., Soutar, G. N., \& Mazzarol, T. (2007). Factors influencing word of mouth effectiveness: Receiver perspectives. European Journal of Marketing, 42(34), 344-364. https://doi.org/10.1108/03090560810852977

Tekin, G., Yiltay, S., \& Ayaz, E. (2016). The Effect of Brand Image on Consumer Behaviour: Case Study of Louiss Vuitton-Moet Hennessy. International Journal of Academic Value Studies (Javstudies JAVS), 2(2), 1-24. https://doi.org/10.23929/javs.47

Tripathi, G. (2017). Customer Satisfaction and Word of Mouth Intentions : Testing The Mediating Effect of Customer Loyalty. Journal of Services Research, 17(2), 1-16. Tuškej, U., Golob, U., \& Podnar, K. (2013). The role of consumer-brand identification in building brand relationships. Journal of Business Research, 66(1), 53-59. https://doi.org/10.1016/j.jbusres.2011.07.022

Wahyu, A. A. G. A. H., \& Gorda, A. A. N. E. S. (2017). Kualitas Produk, Kualitas Pelayanan Terhadap Word of Mouth Dengan Kepuasan Konsumen Dan Loyalitas Pelanggan Sebagai Variabel Intervening. Jurnal Ilmiah Manajemen \& Bisnis, 2(2), $324-336$.

Wijaya, A. F. B., Surachman, S., \& Mugiono, M. (2020). THE EFFECT OF SERVICE QUALITY , PERCEIVED VALUE AND MEDIATING EFFECT OF BRAND IMAGE ON BRAND TRUST. Jurnal Manajemen Dan Kewirausahaan, 22(1), 45-56. https://doi.org/10.9744/jmk.22.1.45

Yaman, Z. (2018). The effect of word of mouth marketıng on the purchase behavior via brand image and perceived quality. Montenegrin Journal of Economics, 14(2), 175-182. https://doi.org/10.14254/1800-5845/2018.14-2.12

Yildiz, E. (2017). Effects of Service quality on Customer Satisfaction, trust, Customer Loyalty and Word of Mouth: An Apllication on Cargo Companies in Gumushane. Global Journal of Economics and Business Studies, 6(12), 81-88.

Zehir, C., \& Narcıkara, E. (2016). E-Service quality and E-Recovery Service quality: Effects on Value Perceptions and Loyalty Intentions. Procedia - Social and Behavioral Sciences, 229, 427-443. https://doi.org/10.1016/j.sbspro.2016.07.153 Zeithaml, V. A., Bitner, M. J., \& Gremler, D. D. (2017). Services Marketing. In 
Dictionary of Marketing Communications (7th ed.). McGraw-Hill Companies. https://doi.org/10.4135/9781452229669.n3303

Appendix

\section{KUESIONER}

\section{Petunjuk Pengisian :}

1. Responden dimohon mengisi kolom profil responden sebelum menjawab pertanyaan dalam kuesioner.

2. Responden dimohon mengisi kuesioner dengan menjawab seluruh pernyataan yang telah disediakan.

3. Berilah tanda $(\sqrt{ })$ pertanyaan berikut sesuai dengan keadaan yang sesunguhnya pada kolom yang tersedia.

\begin{tabular}{|c|c|c|}
\hline Predikat & Keterangan & Bobot \\
\hline SS & Sangat Setuju & 5 \\
\hline S & Setuju & 4 \\
\hline N & Netral & 3 \\
\hline TS & Tidak Setuju & 2 \\
\hline STS & Sangat Tidak Setuju & 1 \\
\hline
\end{tabular}

\section{Identitas Responden :}

1. Jenis Kelamin

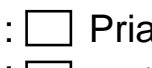

2. Usia

$<20$ tahun
$21-30$ tahun
$31-40$ tahun
$>41$ tahun
Pertama Kali
2 Kali
$3-4$ Kali
$>4$ Kali

\begin{tabular}{|c|l|l|l|l|l|l|}
\hline \multicolumn{8}{|c|}{ KUALITAS PELAYANAN } \\
\hline No & Pernyataan & SS & S & N & TS & STS \\
\hline \multicolumn{7}{|l|}{ Tangibles } \\
\hline 1 & $\begin{array}{l}\text { Fasilitas dan pelayanan di Hotel } \\
\text { Menara Peninsula baik. }\end{array}$ & & & & \\
\hline 2 & $\begin{array}{l}\text { Staf di Hotel Menara Peninsula } \\
\text { berpenampilan rapi dan menarik. }\end{array}$ & & & & \\
\hline
\end{tabular}




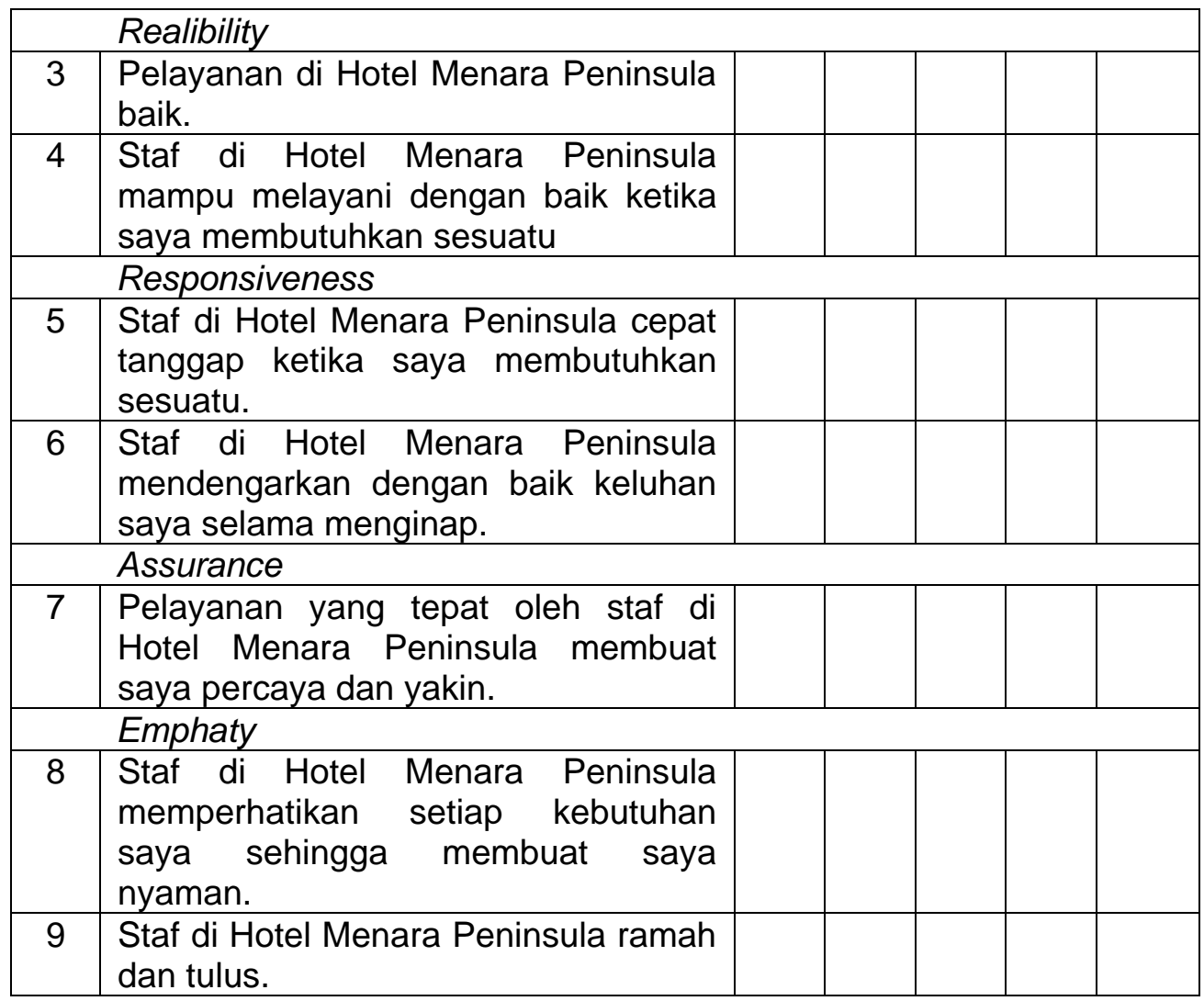

\begin{tabular}{|c|c|c|c|c|c|c|}
\hline \multicolumn{7}{|c|}{ WORD OF MOUTH } \\
\hline No & Pernyataan & SS & $\mathrm{S}$ & $\mathrm{N}$ & TS & STS \\
\hline \multicolumn{7}{|c|}{ Menceritakan Pengalaman Mengkonsumsi } \\
\hline 1 & $\begin{array}{l}\text { Saya akan menceritakan pengalaman } \\
\text { menginap di Hotel Menara Peninsula } \\
\text { kepada orang yang saya kenal. }\end{array}$ & & & & & \\
\hline 2 & $\begin{array}{l}\text { Semakin sering saya menginap di } \\
\text { Hotel Menara Peninsula, saya akan } \\
\text { semakin suka menceritakan } \\
\text { pengalaman saya kepada orang lain } \\
\text { yang saya kenal. }\end{array}$ & & & & & \\
\hline \multicolumn{7}{|c|}{ Merekomendasikan Merek } \\
\hline 3 & $\begin{array}{l}\text { Saya akan merekomendasikan Hotel } \\
\text { Menara Peninsula kepada orang lain. }\end{array}$ & & & & & \\
\hline 4 & $\begin{array}{l}\text { Saya akan menyarankan Hotel } \\
\text { Menara Peninsula ketika ada yang } \\
\text { membutuhkan informasi. }\end{array}$ & & & & & \\
\hline \multicolumn{7}{|c|}{ Membicarakan Merek Yang Memiliki Produk/Layanan Yang Baqus } \\
\hline 5 & $\begin{array}{l}\text { Saya menceritakan Hotel Menara } \\
\text { Peninsula karena bagus. }\end{array}$ & & & & & \\
\hline 6 & $\begin{array}{l}\text { Saya suka membicarakan } \\
\text { produk/layanan yang bagus dari Hotel } \\
\text { Menara Peninsula. }\end{array}$ & & & & & \\
\hline
\end{tabular}




\begin{tabular}{|c|c|c|c|c|c|c|}
\hline \multicolumn{7}{|c|}{ CITRA MEREK } \\
\hline No & Pernyataan & SS & $\mathrm{S}$ & $\mathrm{N}$ & TS & STS \\
\hline \multicolumn{7}{|c|}{ Keunggulan Asosiasi Merek } \\
\hline 1 & $\begin{array}{l}\text { Hotel Menara Peninsula adalah hotel } \\
\text { dengan citra merek yang baik dan } \\
\text { terpercaya }\end{array}$ & & & & & \\
\hline 2 & $\begin{array}{l}\text { Hotel Menara Peninsula adalah hotel } \\
\text { yang selalu saya ingat. }\end{array}$ & & & & & \\
\hline \multicolumn{7}{|c|}{ Kekuatan Asosiasi Merek } \\
\hline 3 & $\begin{array}{l}\text { Kepopuleran Hotel Menara Peninsula } \\
\text { membuat saya tertarik untuk } \\
\text { menginap. }\end{array}$ & & & & & \\
\hline 4 & $\begin{array}{l}\text { Hotel Menara Peninsula sudah } \\
\text { dikenal masyarakat luas. }\end{array}$ & & & & & \\
\hline \multicolumn{7}{|c|}{ Keunikan Asosiasi Merek } \\
\hline 5 & $\begin{array}{l}\text { Hotel Menara Peninsula memiliki } \\
\text { desain ruangan dan ciri khas yang } \\
\text { unik. }\end{array}$ & & & & & \\
\hline
\end{tabular}

